\title{
Wood Surface Finishing of Selected Invasive Tree Species
}

\section{Površinska obrada nekih invazivnih vrsta drva}

\author{
Original scientific paper • Izvorni znanstveni rad \\ Received-prispjelo: 20. 10. 2019. \\ Accepted-prihvaćeno: 28. 4. 2020. \\ UDK: $630 * 829$ \\ https://doi.org/10.5552/drvind.2020.1955
}

\author{
(C) 2020 by the author(s). \\ Licensee Faculty of Forestry, University of Zagreb. \\ This article is an open access article distributed \\ under the terms and conditions of the \\ Creative Commons Attribution (CC BY 4.0) license.
}

\begin{abstract}
Due to their strong renewal power, the invasive tree species are spreading rapidly, especially in abandoned agricultural and forest areas and along traffic routes and water courses. One way of their restriction is the promotion of their use. In our research, we investigated surface finishing of wood of five selected invasive species in Slovenia, Box elder (Acer negundo L.), Black locust (Robinia pseudoacacia L.), Horse-chestnut (ㅅesculus hippocastanum L.), Honey locust (Gleditsia triacanthos L.) and Chinese sumac (Ailanthus altissima (Mill.) Swingle), and compared it with the finishing of the European beech (Fagus sylvatica L.) wood. For coatings, we selected one-component waterborne finish on acrylate-polyurethane basis, one-component solventborne finish on polyurethane basis and tung oil as a natural finish. Several surface properties were investigated. We proved that surface hardness, resistance to impact and adhesion were very much related to interactions between the coating and the substrate, while resistance to cold liquids was only dependant on the type of the finish. It was also shown that, in general, finishing of woods of selected invasive tree species was not problematic. The only exception was Black locust wood on which tung oil cured very slowly.
\end{abstract}

Keywords: coating, finishing; invasive tree species; oil; wood

SAŽETAK • Invazivne vrste drva brzo se šire zbog izrazito jakog svojstva obnavljanja, posebice na zapuštenim poljoprivrednim $i$ šumskim površinama te uz prometnice $i$ vodotokove. Jedan od načina ograničavanja njihova širenja jest poticanje uporabe njihova drva. U ovom smo istraživanju proučavali površinsku obradu pet invazivnih vrsta drva u Sloveniji: negundovca (Acer negundo L.), bagrema (Robinia pseudoacacia L.), divljeg kestena (Aesculus hippocastanum L.), gledičije (Gleditsia triacanthos L.) i pajasena (Ailanthus altissima (Mill.) Swingle), u usporedbi s površinskom obradom bukovine (Fagus sylvatica L.). Kao premazni materijali upotrijebljeni su jednokomponentni vodeni lak na bazi poliakrilata i poliuretana, jednokomponentni otapajući poliuretanski lak $i$ tungovo ulje kao prirodni premazni materijal. Pritom je ispitivano nekoliko svojstava površine. Dokazano je da tvrdoća površine, otpornost na udarce i adhezija izrazito ovise o međudjelovanju premaza i podloge, a otpornost na hladne tekućine ovisi samo o vrsti premaza. Također je dokazano da površinska obrada promatranih invazivnih vrsta drva nije problematična. Izuzetak je drvo bagrema, na kojemu se tungovo ulje vrlo sporo suši.

Ključne riječi: premaz; površinska obrada; invazivne vrste drva; ulje; drvo

1 INTRODUCTION

1. UVOD

According to the definition of the International Union for Conservation of Nature (IUCN), invasive alien species (IAS) is an alien species that has stabi- lized and is causing environmental change, threatening human health, the economy and/or native biotic variety (Bačič and Strgulc Krajšsek, 2013). Due to their strong renewal power, the invasive tree species are spreading rapidly, especially in abandoned agricultural and forest

\footnotetext{
${ }^{1}$ Authors are teaching assistant, PhD candidate and full professor at University of Ljubljana, Biotechnical Faculty, Department of Wood Science and Technology, Ljubljana, Slovenia.
} 
areas and along traffic routes and water courses. One way of their restriction is the promotion of their use.

The optimal processing of wood species for high added value products is only possible with a thorough knowledge of the basic properties of the raw materials. Some properties also restrict the use of certain wood species. In our previous research, 17 Slovenian wood IAS were identified as suitable for processing into wood products. Several species grow as ornamental shrubs and as such are not interesting for technological exploitation. Therefore, the research was more focused on species from which a sufficient quantity of wood could be obtained for carrying out the tests. Those were Box elder (Acer negundo L.), Black locust (Robinia pseudoacacia L.), Horse-chestnut (Aesculus hippocastanum L.), Honey locust (Gleditsia triacanthos L.) and Chinese sumac (Ailanthus altissima (Mill.) Swingle). The following properties were investigated: physical-mechanical properties, basic chemical composition with specificities, machinability, gluing properties, durability and impregnability (Merela et al., 2019). However, no research has been made about the wood surface finishing yet. Also, in the literature, only few investigations can be found.

Nemeth et al. (2014) performed an evaluation of Black locust strip parquet flooring panels after longterm, in-service exposure. By controlled steam treatment prior to oiling, they further increased the utilization potential of this material. After 5 years of in-service and laboratory tests, they concluded that oil treatment of wood did not contribute significantly to a higher performance of the parquet compared to the untreated one. According to Pánek and Reinprecht (2014), the Black locust was usually shown as better wood substance for transparent paints in comparison to the Norway spruce (Picea abies (L.) Karst) wood, evaluating colour stability and rate of surface destruction at natural weathering. Later on, Pánek and Reinprecht (2016) investigated the impact of the number of coats on the colour stability and the surface defects of painted Black locust and Norway spruce woods after up to three years of natural weathering. The colour stability of the surfaces and their resistance to defects was better when the coating system was applied to Black locust wood compared with Norway spruce wood. Smoother surfaces of wood before painting resulted in a higher resistance against cracking and other defects caused by natural weathering; however, the effect of the initial wood roughness on the colour stability of painted woods during natural weathering was negligible. On the same woods, Pánek and Reinprecht (2019) also showed some possibilities for predicting changes in the colour of painted wood in the exterior by its accelerated weathering in Xenotest, using suitable correlation analyses.

Kúdela et al. (2016) focused on the influence of accelerated ageing on surface-treated Chinese sumac wood veneers. The observed coating system had a high resistance against photo-degradation under the dry mode, while under the wet mode (UV radiation with rainfall simulation) some colour changes were present. They established that bigger amounts of dark pigments in the coatings resulted in better protection of the Chinese sumac wood surface against UV-induced degradation. Further on, Kúdela et al. (2017) evaluated accelerated ageing effects on quality of Chinese sumac wood surface finished with a water-based coating system applied in several colour hues, and concluded that the colour variability of the coating system had no effects on roughness, wetting performance and surface free energy values.

The red stain common in Box elder wood appears to be created by the tree as a response to wounding. Wood displaying this pigment is commonly used in decorative woodturning. Unfortunately, when the pigment is exposed to UV light, it is degraded regardless of the used coating (Robinson et al., 2013).

In the case of wood surface finishing with usually thin coating films, the properties of the finished surface depend not only on the final coat but also on the layers just below the top and definitely on the substrate itself. There is a synergy between the coating system (consisting of one or more layers of the same or different coating materials) and wood substrate. All this forms the so-called surface system, which determines the quality of all constituents (Pavlič et al., 2003). Therefore, protection or resistance of the wooden structure against physical and chemical influences can be obtained by surface treatment, which depends on the selected coating and the type of substrate (Keskin and Tekin, 2011; Veigel et al., 2014). Substrate properties, such as structure, density, surface roughness, chemical composition and colour may influence the effect of the coating. In indoor applications, the mechanical coating properties, like surface hardness, deformability as well as resistance to impact, friction, scratch and abrasion, are of prime importance (Brischke et al., 2019).

In our research, we investigated the surface finishing of wood of five above mentioned invasive species in Slovenia, Box elder, Black locust, Horse-chestnut, Honey locust and Chinese sumac, and compared it with the finishing of the European beech wood. For coatings, we selected one-component waterborne finish on acrylate-polyurethane basis, one-component solventborne finish on polyurethane basis and tung oil, as a natural finish. We presumed that interactions between wood substrates and selected finishes are suitable to achieve quality surface systems that will be investigated by the determination of several properties.

\section{MATERIALS AND METHODS}

\section{MATERIJALI I METODE}

\subsection{Sample preparations}

\subsection{Priprema uzoraka}

We prepared three boards with radial orientation of the growth rings and dimensions of $(800 \times 120 \times 20)$ $\mathrm{mm}$ from dry wood for each wood species (Table 1). After machining, the boards were kept for one week at a temperature of $(23 \pm 2){ }^{\circ} \mathrm{C}$ and a relative humidity of $(50 \pm 5) \%$. Before application of finishes, the boards were sanded with a P180 grit size sand paper and sawn into three equal parts. In this way, for each wood species, we prepared three sets of three sequential sam- 
Table 1 Used wood species and their abbreviations Tablica 1. Ispitivane vrste drva i njihove kratice

\begin{tabular}{|l|c|}
\hline \multicolumn{1}{|c|}{$\begin{array}{c}\text { Wood species } \\
\text { Vrsta drva }\end{array}$} & $\begin{array}{c}\text { Abbreviation } \\
\text { Kratica }\end{array}$ \\
\hline $\begin{array}{l}\text { European beech } \\
\text { Obična bukva (Fagus sylvatica L.) }\end{array}$ & FaSy \\
\hline $\begin{array}{l}\text { Box elder } \\
\text { Negundovac (Acer negundo L.) }\end{array}$ & AcNe \\
\hline $\begin{array}{l}\text { Black locust } \\
\text { Bagrem (Robinia pseudoacacia L.) }\end{array}$ & RoPs \\
\hline $\begin{array}{l}\text { Horse-chestnut } \\
\text { Divlji kesten (Aesculus hippocastanum L.) }\end{array}$ & AeHi \\
\hline $\begin{array}{l}\text { Honey locust } \\
\text { Gledičija (Gleditsia triacanthos L.) }\end{array}$ & GlTr \\
\hline $\begin{array}{l}\text { Chinese sumac } \\
\text { Pajasen (Ailanthus altissima (Mill.) } \\
\text { Swingle) }\end{array}$ & AiAl \\
\hline
\end{tabular}

ples, one for each finish. Prior to finishing, the colour of the wood surface was determined.

For finishing, we selected unpigmented semi-gloss one-component waterborne coating on acrylate-polyurethane basis (WPU), unpigmented glossy one-component solventborne finish on polyurethane basis (SPU) and tung oil (TO). The coatings were applied with manual quadruple film applicator (Model 360, ERICHSEN GmbH \& Co. KG, Hemer, Germany) at an application gap height of $180 \mu \mathrm{m}$ and a speed of $(3 \pm 0.5) \mathrm{cm} / \mathrm{s}$. The tung oil was hand-rubbed by a cotton cloth and after 10 minutes wiped off with a dry one. All finishes were applied two times, without intermediate sanding. The drying time between the first and second application was $24 \mathrm{~h}$.

After the finishing, samples were conditioned at a temperature of $(23 \pm 2){ }^{\circ} \mathrm{C}$ and a relative humidity of $(50 \pm 5) \%$ for 21 days, and the following properties were investigated: colour, gloss, dry coating film thickness, coating adhesion, finished surface resistance to cold liquids, coated surface hardness and resistance to impact. The drying stage of the oiled surfaces was monitored already after $24 \mathrm{~h}$ from the last application.

In addition, special samples were prepared for the measurement of coating material sorption, coating hardness and attenuated total reflection Fourier transform infrared (ATR FT-IR) spectroscopy.

\subsection{Sorption measurements}

\subsection{Mjerenje sorpcije}

For the measurement of the coating material sorption, for each substrate, we prepared 15 (5 for each finish) sequential samples with a radial ring orientation, of a normal growth rate, and cross section of (15 $\times 15) \mathrm{mm}$ and longitudinal dimension of $30 \mathrm{~mm}$. Samples were mounted into the tensiometer (K100MK2, KRÜSS GmbH, Hamburg, Germany), where the cross section was immersed into the coating material for 1 $\mathrm{mm}$. The mass gain was monitored for further $200 \mathrm{~s}$, without changing the position of the sample.

\subsection{Determination of the drying stage}

2.3. Određivanje stupnja osušenosti uljem premazane površine

Determination of the drying stage of oiled surfaces was monitored according to DIN 53150 (2002) on the first set of sequential coated samples of each substrate. A paper disc with a diameter of $26 \mathrm{~mm}$ and grammage of $80 \mathrm{~g} / \mathrm{m}^{2}$ was placed on the surface and loaded with a mass of $20 \mathrm{~g}$ for $60 \mathrm{~s}$. Later on, the surface was examined for any changes. If the surface was not damaged, the procedure was repeated and a paper disc was loaded with the higher mass, until the final, $7^{\text {th }}$ drying stage was reached (drying stage 2 - $20 \mathrm{~g}, 3$ - 200 g, $5-2 \mathrm{~kg}, 7-20 \mathrm{~kg}$ ).

\subsection{Determination of coating hardness}

2.4. Određivanje tvrdoće premaza

Coating hardness of WPU and SPU was determined by the pendulum damped oscillations test method with the use of König pendulum tester (Model 299/300, Erichsen GmbH \& Co. KG, Hemer, Germany; EN ISO $1522,2007)$. The coatings were applied on a glass plates with manual quadruple film applicator (Model 360, ERICHSEN GmbH \& Co. KG, Hemer, Germany) at an application gap height of $360 \mu \mathrm{m}$ and a speed of $(3 \pm 0.5) \mathrm{cm} / \mathrm{s}$. After drying and conditioning at $(23 \pm 2){ }^{\circ} \mathrm{C}$ and a relative humidity of $(50 \pm 5) \%$ for 21 days, the coating hardness was measured ( 3 samples per coating, 5 measurements per sample). The hardness value corresponded to the damping time of the pendulum oscillating on the coating surface from $6^{\circ}$ to $3^{\circ}$, in respect to normal axis, measured with an electronic counter.

\subsection{Colour measurements}

2.5. Mjerenje boje

The colour of wood surfaces before and after finishing was determined according to CIELAB system (SIST EN ISO 11664-4, 2011) using a spectrophotometer (SP 62, X-Rite Pantone, Grand Rapids, MI USA) with diffuse $/ 8^{\circ}$ sphere optical geometry, fixed $14 \mathrm{~mm}$ aperture, specular component included, illuminant D65 and a $10^{\circ}$ standard observer. For each sample (3 samples per wood species for each finish), ten measurements were performed and the average values were recorded. The colour differences $\left(\Delta E^{*}\right)$ between untreated wood and 21 days after the finishing were calculated as follows:

$$
\begin{gathered}
\Delta L^{*}=\Delta L^{*}{ }_{1}-\Delta L_{0}^{*} \\
\Delta a^{*}=\Delta a^{*}{ }_{1}-\Delta a^{*}{ }_{0} \\
\Delta b^{*}=\Delta b^{*}{ }_{1}-\Delta b^{*}{ }_{0} \\
\Delta E^{*}=\left(\Delta L^{* 2}+\Delta a^{* 2}+\Delta b^{* 2}\right)^{1 / 2}
\end{gathered}
$$

where $\Delta E^{*}$ represents the total colour difference, $L^{*}$ is the lightness and darkness of colour, $a^{*}$ is the redness and greenness of colour, $b^{*}$ is the yellowness and blueness of colour, and $\Delta L^{*}, \Delta a^{*}$, and $\Delta b^{*}$ are the differences of the finished $\left(_{1}\right)$ and untreated wood surface $\left(_{0}\right)$ of $L^{*}, a^{*}$, and $b^{*}$, respectively (Wang et al., 2017). During colour measurements, any anomalies on the surface, like brown to red stain spots on Box elder wood, were avoided. We must also point out that, in case of coloured heartwood species (Black locust and Honey locust), only heartwood was used in our research. 


\subsection{Gloss measurements}

2.6. Mjerenje sjaja

The specular gloss of coated surfaces 21 days after the finishing was determined with gloss meter (AcuGloss TRI, X-Rite Pantone, Grand Rapids, MI USA) according to the method described in EN ISO 2813 (2015). Ten measurements of each sample (3 samples per wood species for each finish) were made and the average value was reported.

\subsection{Dry film thickness}

2.7. Debljina filma osušenog premaza

Dry coating film thickness of WPU and SPU was measured using the microscopic method according to SIST EN ISO 2808:2007. We prepared cross sections of the coated systems, which were observed under the Olympus SZH stereomicroscope with additional illumination and 120x magnification. As a result, the representative (average) value was reported (3 cross sections per coating, 5 measurements per sample).

\subsection{Coating adhesion}

Coating adhesion of WPU and SPU was determined using a pull-off test described in SIST EN ISO 4624 (2016). For this, we used the first set of sequential coated samples of each substrate. On each coated surface, ten dollies were glued, using an epoxy adhesive (UHU plus endfest 300, UHU, Bühl, Germany). After 24 hours, the cured epoxy adhesive and the coating were cut to the substrate around the circumference of the dolly and the test was conducted using a PosiTest AT adhesion tester (DeFelsco Corporation, Ogdensburg, NY, USA). A tensile stress was applied at an increasing speed not greater than $1 \mathrm{MPa} / \mathrm{s}$ until the dolly was pulled-off. The breaking strength (in $\mathrm{MPa}$ ) and the nature of the fracture were recorded.

\subsection{Assessment of surface resistance to cold liquids \\ 2.9. Procjena otpornosti površine na hladne tekućine}

Assessment of finished wood surface resistance to cold liquids was performed using the method described in SIST EN 12720 (2009). For this, we used the second set of sequential finished samples of each substrate. Paper discs (diameter of $25 \mathrm{~mm}$ and a grammage of $450 \mathrm{~g} / \mathrm{m}^{2}$ ) saturated with the test liquids (water, coffee, red vine and alcohol $-45 \%$ ethanol; immersed for $30 \mathrm{~s}$ ) were placed on the test surface and covered by a specified glass Petri dish. After a $1 \mathrm{~h}$ test period, the discs were removed and the test surface was left for $20 \mathrm{~h}$. Thereafter, the test surface was cleaned and after 30 min examined for damages, such as discolouration, change in gloss, change in colour, blistering and swelling. The examination was performed in the laboratory light environment and in the standardised viewing cabinet. The test result was stated in a numerical rating code from 5 (no change) to 1 (strong change).

\subsection{Surface hardness - Scratch test} 2.10. Tvrdoća površine - ispitivanje grebanjem

The hardness of the coated surfaces was measured indirectly by the SIST EN ISO 1518:2001 scratch test. For this, we used the third set of sequential finished samples of each substrate. We used the so-called spring test pencil (Model 318, Erichsen GmbH \& Co. $\mathrm{KG}$, Hemer, Germany). A needle is inserted in it with a tip of a half-shaped sphere of $1 \mathrm{~mm}$ in diameter. The load on the tip can vary (from $1 \mathrm{~N}$ to $20 \mathrm{~N}$ ), which is adjusted by moving the slip ring, pressing inside the inserted spring. With this spring pencil, we scratched the surface in a length of at least $60 \mathrm{~mm}$. The scratch speed was between $30 \mathrm{~mm} / \mathrm{s}$ and $40 \mathrm{~mm} / \mathrm{s}$ and the scratch was performed perpendicular to the grain direction. We increased the load to the tip to the extent that cracks in the coating film appeared or the width of the trace (plastic deformation) was greater than $0.5 \mathrm{~mm}$. The greater the load (force) is, the more the coated surface is resistant to scratching and consequently is harder.

\subsection{Resistance to impact \\ 2.11. Otpornost na udarce}

To determine the resistance to impact of a coated surface (WPU and SPU), the method SIST ISO 42114:1995 was used by descending the weight of $(500 \pm 5) \mathrm{g}$ from different heights $(10 \mathrm{~mm}, 25 \mathrm{~mm}$, $50 \mathrm{~mm}, 100 \mathrm{~mm}$, and $200 \mathrm{~mm}$ ) on a steel ball with a diameter of $14 \mathrm{~mm}$. For this, we also used the second set of sequential coated samples of each substrate, on which resistance to cold liquids was also measured. After the impacts, the surface was carefully examined, also with a magnifier (10x magnification). The resistance of the surface to impacts (average value) from different heights was evaluated with numerical grades from 5 (no change) to 1 (strong change). From each height, 5 impacts were performed and the nearest whole number to the mean was reported. The dropping height was increased until the first cracks in coating film occurred (grade 3).

\subsection{Attenuated total reflection Fourier transform infrared (ATR FT-IR) spectroscopy}

2.12. Infracrvena spektroskopija uz prigušenu totalnu refleksiju (ATR FT-IR)

ATR FT-IR spectroscopic measurements of the dry coating film were performed using a Perkin Elmer Spectrum Two spectrometer (PerkinElmer Inc., Waltham, Massachusetts, USA), with a $\mathrm{LiTaO}_{3}$ detector in the absorbance mode. The spectra were measured on 3 different spots (16 scans per spot) of each sample, at a wavelength range from $600 \mathrm{~cm}^{-1}$ to $4000 \mathrm{~cm}^{-1}$ and at a resolution of $0.5 \mathrm{~cm}^{-1}$.

\section{RESULTS AND DISCUSSION}

\section{REZULTATI I RASPRAVA}

\subsection{Oil sorption and drying stage of oiled} surfaces

3.1. Sorpcija ulja i stupanj osušenosti površine premazane uljem

Drying stage of the oiled surfaces was monitored already $24 \mathrm{~h}$ after the last application. Yang et al. (2015) reported that tung oil usually requires more than 5 days to dry. This correlates with our findings, in which tung oil reached the final drying stage after 


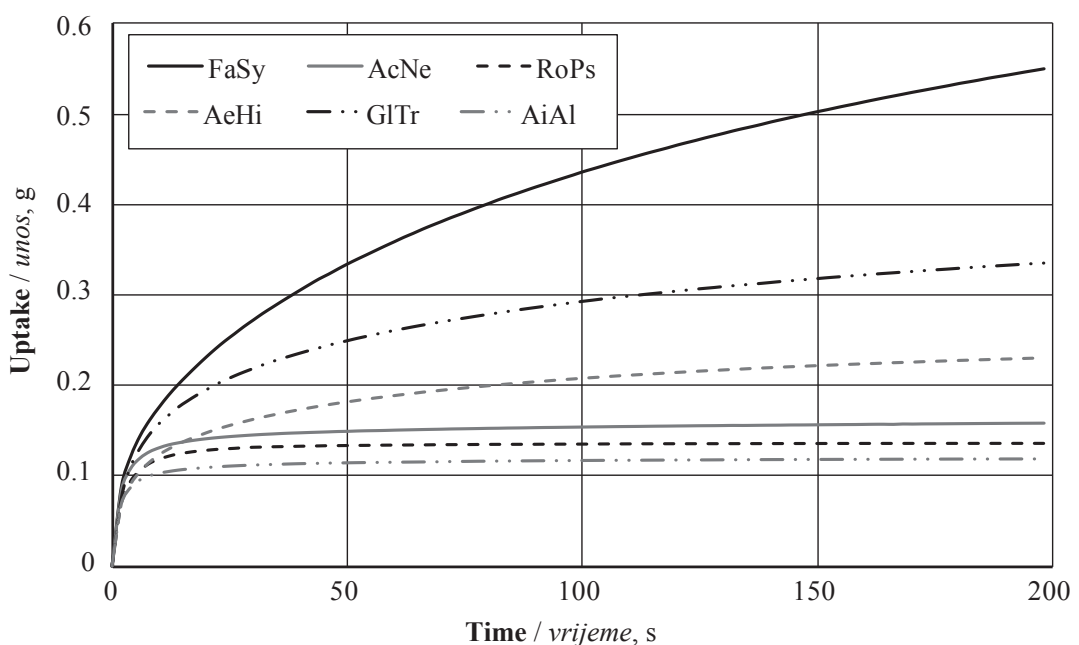

Figure 1 Sorption of tung oil

Slika 1. Sorpcija tungova ulja

Table 2 Drying time of oiled surfaces

Tablica 2. Vrijeme sušenja površina premazanih uljem

\begin{tabular}{|c|c|c|c|c|}
\hline \multirow{2}{*}{$\begin{array}{c}\text { Substrate } \\
\text { Podloga }\end{array}$} & \multicolumn{4}{|c|}{ Drying stage / Faza sušenja } \\
\cline { 2 - 5 } & 2 & 3 & 5 & 7 \\
\multirow{2}{*}{ FaSy } & 1 day & 1 day & 2 days & 7 days \\
& 1 dan & 1 dan & 2 dana & 7 dana \\
\hline \multirow{2}{*}{$\mathrm{AcNe}$} & $\begin{array}{c}1 \text { day } \\
1 \text { dan }\end{array}$ & $\begin{array}{c}1 \text { day } \\
1 \text { dan }\end{array}$ & $\begin{array}{c}2 \text { days } \\
2 \text { dana }\end{array}$ & $\begin{array}{c}7 \text { days } \\
\text { dana }\end{array}$ \\
\hline \multirow{2}{*}{$\mathrm{RoPs}$} & 7 days & 13 days & 17 days & 25 days \\
& 7 dana & 13 dana & 17 dana & 25 dana \\
\hline \multirow{2}{*}{$\mathrm{AeHi}$} & 2 days & 2 days & 5 days & 10 days \\
& 2 dana & 2 dana & 5 dana & 10 dana \\
\hline \multirow{2}{*}{$\mathrm{GlTr}$} & 1 day & 1 day & 2 days & 7 days \\
& 1 dan & 1 dan & 2 dana & 7 dana \\
\hline \multirow{2}{*}{$\mathrm{AiAl}$} & 2 days & 2 days & 5 days & 10 days \\
& 2 dana & 2 dana & 5 dana & 10 dana \\
\hline
\end{tabular}

7 days of drying on beech, box elder and honey locust wood, but it dried a bit more slowly on horse chestnut and Chinese sumac wood (10 days for d. s. 7), and very slowly on black locust wood, where the final stage was reached only after 25 days (Table 2 ).
We presumed that these results must have been connected with the interactions of the fresh oil with a substrate. The sorption test (Figure 1) showed that the highest uptake into the substrate was indeed in the case of beech and honey locust wood, but the uptake of oil into box elder wood, on which oil dried normally, was quite low and the sorption dynamic was similar to the ones in case of Chinese sumac and black locust wood.

Nevertheless, black locust wood, on which tung oil dried abnormally slowly, has among the observed species one of the lowest uptake of tung oil, the highest density and the highest value of total extractives (Merela et al., 2019). From this, we can conclude that interactions between the substrate and the finish did have an effect on the drying speed of tung oil.

\subsection{Coating sorption and dry film thickness}

3.2. Sorpcija i debljina osušenog premaza

Thickness of the dry coating film depends on properties of wet coating and substrate. Nevertheless, from the results (Table 3 ), we can see that, with the same application parameters on the same substrate,

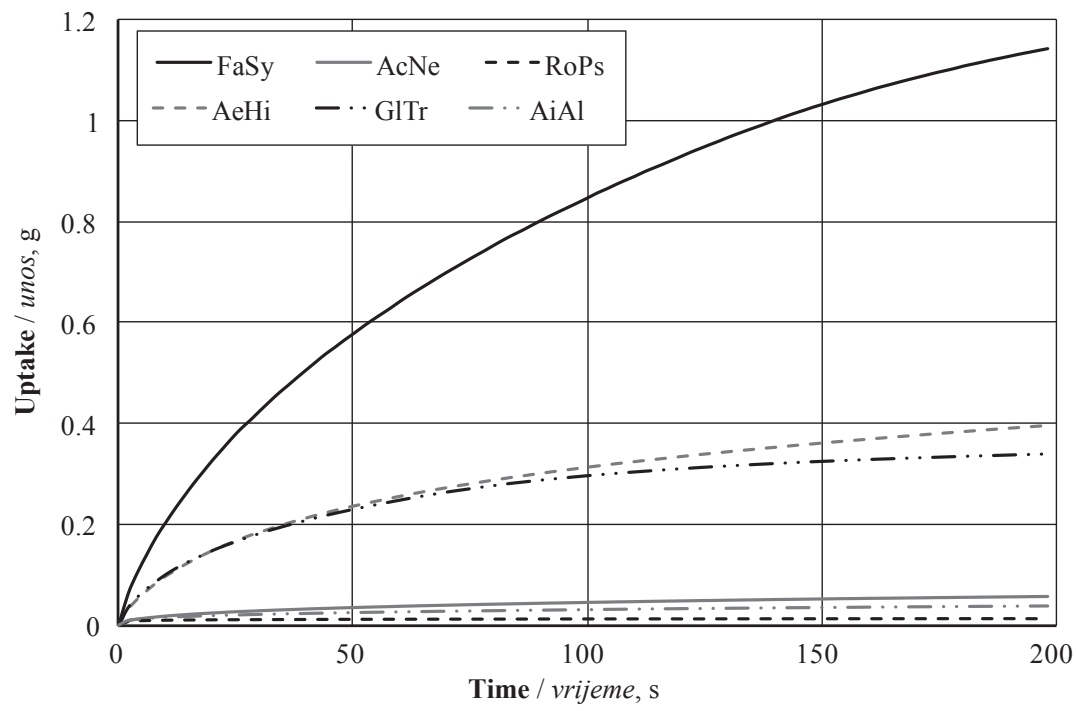

Figure 2 Sorption of one-component solventborne finish on polyurethane basis (SPU)

Slika 2. Sorpcija jednokomponentnoga otapajućeg poliuretanskog premaza (SPU) 
Table 3 Dry coating film thickness

Tablica 3. Debljina suhog filma premaza

\begin{tabular}{|c|c|c|c|c|}
\hline \multirow{2}{*}{$\begin{array}{c}\text { Substrate } \\
\text { Podloga }\end{array}$} & \multicolumn{4}{|c|}{ Thickness / Debeljina, $\mu \mathrm{m}$} \\
\cline { 2 - 5 } & \multicolumn{2}{|c|}{ WPU } & \multicolumn{2}{c|}{ SPU } \\
\hline & $\bar{x}$ & $\sigma$ & $\bar{x}$ & $\sigma$ \\
\hline FaSy & 65 & 4.9 & 42 & 3.9 \\
\hline AcNe & 75 & 4.3 & 60 & 3.8 \\
\hline RoPs & 91 & 6.8 & 75 & 4.2 \\
\hline AeHi & 83 & 5.3 & 58 & 4.0 \\
\hline GlTr & 54 & 5.4 & 50 & 4.1 \\
\hline AiAl & 90 & 5.1 & 73 & 4.3 \\
\hline
\end{tabular}

higher thickness of the dry coating film of WPU was always achieved compared to SPU. This relation is pretty much correlated with the results of coating sorption test. The uptake of SPU on all substrates (Figure 2) was higher than the uptake of WPU (Figure 3). This higher uptake of SPU contributed to a lower thickness of the SPU coating films compared to WPU ones.

In our previous research, we investigated the wood anatomy, chemical, physical and mechanical properties (Merela et al., 2019) of the used IAS. If we correlate this data with our sorption results, we can conclude that the average wood density in oven dry state $\left(\rho_{0}\right)\left(\mathrm{FaSy}-680 \mathrm{~g} / \mathrm{m}^{3}, \mathrm{AcNe}-520 \mathrm{~g} / \mathrm{m}^{3}\right.$, RoPs $678 \mathrm{~g} / \mathrm{m}^{3}, \mathrm{AeHi}-479 \mathrm{~g} / \mathrm{m}^{3}, \mathrm{GlTr}-702 \mathrm{~g} / \mathrm{m}^{3}, \mathrm{AiAl}-$
$602 \mathrm{~g} / \mathrm{m}^{3}$ ) correlates the best with the sorption results (Figure 1, 2 and 3). In general, investigated IAS with higher density have lower uptake of coating material.

\subsection{Colour and gloss of finished surfaces \\ 3.3. Boja i sjaj površinski obrađenog drva}

Colour changes calculated from measurements made 21 days before and after the finishing are shown in Table 4. In general, the coated surfaces with solventborne coating changed the colour the most. The two exceptions are the coated surfaces of black locust and honey locust wood, which changed the colour the most after coating with the waterborne coating. Surfaces became more yellow than the others (RoPs: $\Delta b^{*}=15.27$; GlTr: $\left.\Delta b^{*}=8.6\right)$. This yellowing occurred later on, during the measurements of coating adhesion connected with the yellowing of the coating film due to possible migration of the extractives, as discussed after ATR FT-IR measurements.

Finishing with oil resulted in less colour variability between surfaces and all surfaces became a bit yellowish, as expected (Yang et al., 2015).

The oiled surfaces had the lowest gloss (from 2.18 to 4.55). The gloss of coated surfaces with semi-gloss waterborne coating was from 18.97 to 25.29 . The highest gloss was achieved in the case of finishing with glossy solventborne coating (from 77.44 to 94.12) (Table 5).

Table 4 Changes of colour components $\left(\Delta L^{*}, \Delta a^{*}, \Delta b^{*}\right)$ and total colour difference $\left(\Delta E^{*}\right)$ after finishing

Tablica 4. Promjene komponenti boje $\left(\Delta L^{*}, \Delta a^{*}, \Delta b^{*}\right)$ i ukupne promjene boje $\left(\Delta E^{*}\right)$ nakon površinske obrade

\begin{tabular}{|c|c|c|c|c|c|c|c|c|c|c|c|c|}
\hline \multirow{2}{*}{$\begin{array}{c}\text { Substrate } \\
\text { Podloga }\end{array}$} & \multicolumn{4}{|c|}{ WPU } & \multicolumn{4}{c|}{ SPU } & \multicolumn{4}{c|}{ TO } \\
\cline { 2 - 15 } & $\Delta L^{*}$ & $\Delta a^{*}$ & $\Delta b^{*}$ & $\Delta E^{*}$ & $\Delta L^{*}$ & $\Delta a^{*}$ & $\Delta b^{*}$ & $\Delta E^{*}$ & $\Delta L^{*}$ & $\Delta a^{*}$ & $\Delta b^{*}$ & $\Delta E^{*}$ \\
\hline FaSy & 4.66 & -0.59 & 2.24 & 5.20 & 2.35 & -0.01 & 10.20 & 10.47 & -0.85 & 2.29 & 9.64 & 9.94 \\
\hline AcNe & 0.10 & 0.33 & 1.76 & 1.80 & -4.01 & 1.31 & 11.07 & 11.84 & -1.78 & 1.18 & 9.21 & 9.46 \\
\hline RoPs & -2.40 & -2.73 & 15.27 & 15.69 & -5.86 & 3.62 & 11.10 & 13.06 & -6.75 & 4.38 & 9.82 & 12.69 \\
\hline AeHi & -0.38 & 0.71 & 3.87 & 3.95 & -4.12 & 1.87 & 12.94 & 13.71 & -7.46 & 4.74 & 9.96 & 13.32 \\
\hline GlTr & -1.86 & 0.54 & 8.60 & 8.82 & -0.18 & -1.26 & 3.36 & 3.60 & -3.75 & 2.19 & 8.62 & 9.65 \\
\hline AiAl & -1.50 & -2.48 & 6.56 & 7.18 & -2.66 & -1.77 & 12.72 & 13.11 & -2.84 & -1.82 & 10.76 & 11.28 \\
\hline
\end{tabular}

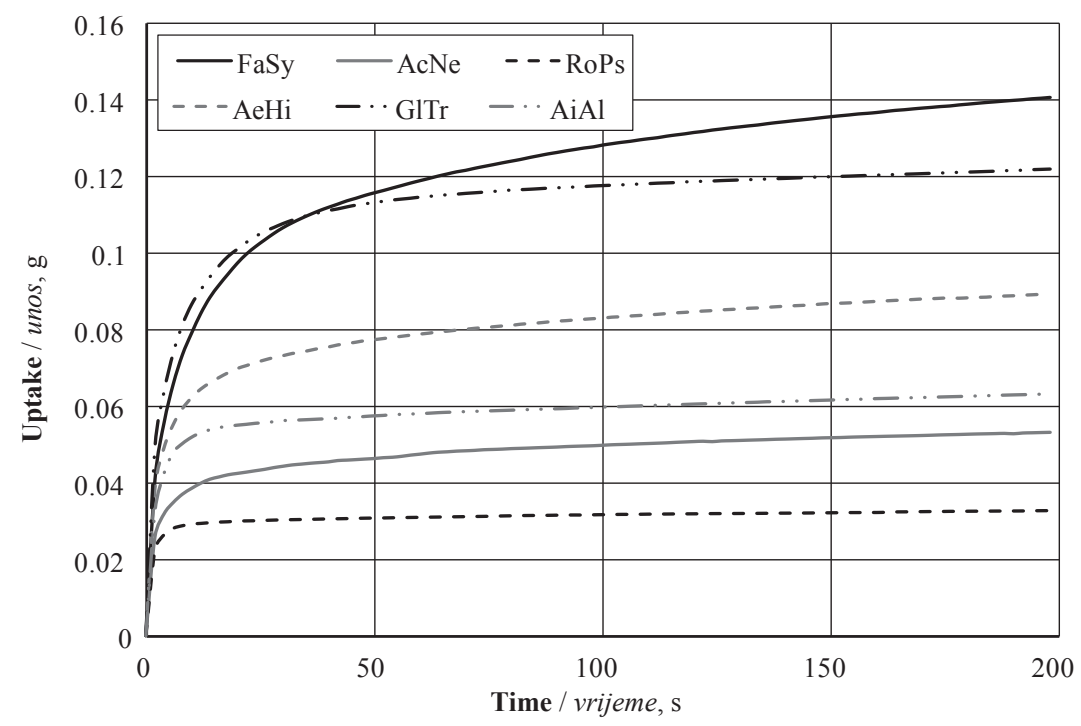

Figure 3 Sorption of one-component waterborne coating on acrylate-polyurethane basis (WPU)

Slika 3. Sorpcija jednokomponentnoga vodenog premaza na bazi poliakrilata i poliuretana (WPU) 
Table 5 Gloss of finished surfaces

Tablica 5. Sjaj površinski obrađenih uzoraka

\begin{tabular}{|c|c|c|c|c|c|c|c|c|c|c|c|c|}
\hline \multirow{2}{*}{$\begin{array}{c}\text { Finish } \\
\text { Premaz }\end{array}$} & \multicolumn{2}{|c|}{ FaSy } & \multicolumn{2}{c|}{ AcNe } & \multicolumn{2}{c|}{ RoPs } & \multicolumn{2}{c|}{ AeHi } & \multicolumn{3}{c|}{ GITr } & \multicolumn{2}{c|}{ AiAl } \\
\cline { 2 - 13 } & $\bar{x}$ & $\sigma$ & $\bar{x}$ & $\sigma$ & $\bar{x}$ & $\sigma$ & $\bar{x}$ & $\sigma$ & $\bar{x}$ & $\sigma$ & $\bar{x}$ & $\sigma$ \\
\hline WPU & 20.84 & 0.96 & 22.97 & 1.27 & 24.73 & 0.36 & 25.29 & 0.44 & 18.97 & 0.82 & 24.34 & 1.08 \\
\hline SPU & 82.46 & 6.16 & 94.12 & 2.58 & 88.86 & 1.23 & 83.04 & 3.97 & 77.44 & 3.14 & 84.74 & 3.72 \\
\hline TO & 4.27 & 0.18 & 4.55 & 0.39 & 2.18 & 0.30 & 3.49 & 0.16 & 3.13 & 0.16 & 3.43 & 0.13 \\
\hline
\end{tabular}

3.4 Coating adhesion

3.4. Adhezija premaza

According to experiences of our Laboratory for wood finishing, the value of coating adhesion of $2 \mathrm{MPa}$ represents the minimum value for a sufficient coating performance in practice (Pavlič et al., 2003). In our research, the coating adhesion was way above this value in all cases (Table 6). The results also show that, on the same substrate, SPU always had better adhesion than WPU. This is nicely correlated with the increased sorption of SPU compared to WPU (Figure 2 and 3).

In the case of diffuse-porous wood species (Table 6, FaSy, AcNe, AeHi), we can observe also the presence of the cohesive fracture of the substrate $(\mathrm{K})$. Obviously, the coatings penetrated into those substrates more evenly and in this way more substrate was anchored with a coating, but of course, the appearance of the cohesive fracture also depends on physical and mechanical properties of wood (Kúdela and Liptáková, 2006). If the cohesive fracture of the substrate appears during the pull-off test, then it means that the coating adhesion is not clear but for sure is above the measured value.

While observing the pulled off coating films, we noticed that the coating film of WPU removed from the RoPs was yellowish, while the substrate underneath preserved its natural colour. Similar, but less intense yellow colouring was also noticed in the case of WPU on GITr. That was the reason why we decided to record ATR-FTIR spectra of WPU on glass (samples from measurements of coating hardness), GlTr and RoPs.

\subsection{Coating and coated surface hardness \\ 3.5. Tvrdoća premaza i premazane površine}

The pendulum hardness test is based on the principle that the harder the measured surface, the greater the oscillation time of the pendulum is. The amplitude of the pendulum oscillation decreases gradually because of the damping during the pendulum hardness test. The pendulum hardness of the coating is greatly related to its dry film thickness (Ma et al., 2013). The coating film of SPU applied on a glass plate (thickness film about $55 \mu \mathrm{m}$ ) had a very low oscillation time of $28.39 \mathrm{~s}$ in average, meaning high damping of the pendulum due to the elastic deformations of the film. The coating film of WPU on glass, despite of a bit higher thickness $(60 \mu \mathrm{m})$, exhibited higher oscillation time (65.54 s), meaning that it had much greater hardness.

It is known that coating hardness greatly depends on the thickness of coating; it gradually decreases with the increasing thickness of coating (Sönmez et al., 2011; Ma et al., 2013; Gurleyen et al., 2017). However, in our research, this was not evident since the coating hardness and type of the substrate had much higher influence on coated surface hardness, determined by the scratch test (Table 7). We can see that surfaces coated with SPU had marks wider than $0.5 \mathrm{~mm}$ at lower forces (FaSy, AcNe) and at the same or higher forces no cracks in the coating film appeared during the scratch test (RoPs, AeHi, GlTr, AiAl), meaning that the surfaces coated with SPU are more flexible than the ones coated with WPU.

The influence of the substrate on coated surface hardness was especially evident in the case of substrates coated with WPU (Table 7). The coating film on the ring-porous wood species (RoPs, GlTr, AiAl) cracked, even at lower scratch forces. This is most often the case of the surface systems with ring-porous substrates when the scratch tip passes the coating on non-totally even filled open wood cell lumens (Pavlič et al., 2003).

\subsection{Impact resistance}

\subsection{Otpornost na udarce}

As a result of the impact resistance of the coated surfaces, the minimum dropping height at which the coating cracked (grade 3 or less) is stated to differ the impact marks at the same height, if relevant (Table 8).

Table 6 Coating adhesion $(\sigma)$ and type of fracture (A - adhesive fracture between coating and substrate, $\mathrm{K}$ - cohesive fracture of substrate)

Tablica 6. Adhezija premaza $(\sigma)$ i vrste loma (A - adhezijski lom između premaza i podloge, $\mathrm{K}$ - kohezijski lom u podlozi)

\begin{tabular}{|c|c|c|c|c|c|c|}
\hline \multirow{3}{*}{$\begin{array}{c}\text { Substrate } \\
\text { Podloga }\end{array}$} & \multicolumn{6}{|c|}{ Adhesion / Adhezija, MPa } \\
\hline & \multicolumn{3}{|c|}{ WPU } & \multicolumn{3}{|c|}{ SPU } \\
\hline & $\bar{x}$ & $\sigma$ & Fracture / Lom & $\bar{x}$ & $\sigma$ & Fracture / Lom \\
\hline FaSy & 4.95 & 0.36 & $70 \% \mathrm{~A}, 30 \% \mathrm{~K}$ & 5.45 & 0.33 & $80 \% \mathrm{~A}, 20 \% \mathrm{~K}$ \\
\hline $\mathrm{AcNe}$ & 4.09 & 0.29 & $20 \% \mathrm{~A}, 80 \% \mathrm{~K}$ & 4.11 & 0.30 & $85 \% \mathrm{~A}, 15 \% \mathrm{~K}$ \\
\hline RoPs & 4.47 & 0.48 & $100 \% \mathrm{~A}$ & 4.58 & 0.41 & $100 \% \mathrm{~A}$ \\
\hline $\mathrm{AeHi}$ & 3.98 & 0.33 & $25 \% \mathrm{~A}, 75 \% \mathrm{~K}$ & 4.01 & 0.29 & $20 \% \mathrm{~A}, 80 \% \mathrm{~K}$ \\
\hline GlTr & 4.56 & 0.45 & $100 \% \mathrm{~A}$ & 4.89 & 0.44 & $100 \% \mathrm{~A}$ \\
\hline $\mathrm{AiAl}$ & 4.05 & 0.43 & $100 \% \mathrm{~A}$ & 5.12 & 0.42 & $100 \% \mathrm{~A}$ \\
\hline
\end{tabular}


Table 7 Coated surface resistance to scratching with the type of scratch mark ( $\mathrm{w}$ - wider than $0.5 \mathrm{~mm}, \mathrm{c}-$ the presence of cracks in coating film) and dry coating film thickness

Tablica 7. Otpornost površine na ogrebotine s oznakom tipa ogrebotine ( $\mathrm{w}$ - širina veća od $0,5 \mathrm{~mm}, \mathrm{c}$ - pukotina vidljiva na premazu) i debljina suhog filma premaza

\begin{tabular}{|c|c|c|c|c|}
\hline \multirow{2}{*}{$\begin{array}{c}\text { Substrate } \\
\text { Podloga }\end{array}$} & \multicolumn{2}{|c|}{ WPU } & \multicolumn{2}{c|}{ SPU } \\
\cline { 2 - 5 } & $\begin{array}{c}\text { Resist. to scratching } \\
\text { Otpornost na ogrebotine }\end{array}$ & $\begin{array}{c}\text { Thickness, } \boldsymbol{\mu m} \\
\text { Debljina, } \mu \mathrm{m}\end{array}$ & $\begin{array}{c}\text { Resist. to scratching } \\
\text { Otpornost na ogrebotine }\end{array}$ & $\begin{array}{c}\text { Thickness, } \boldsymbol{\mu m} \\
\text { Debljina, } \mu \mathrm{m}\end{array}$ \\
\hline $\mathrm{FaSy}$ & $11 \mathrm{~N}, \mathrm{w}$ & 65 & $10 \mathrm{~N}, \mathrm{w}$ & 42 \\
\hline $\mathrm{AcNe}$ & $11 \mathrm{~N}, \mathrm{w}$ & 75 & $10 \mathrm{~N}, \mathrm{w}$ & 60 \\
\hline $\mathrm{RoPs}$ & $4 \mathrm{~N}, \mathrm{c}$ & 91 & $9 \mathrm{~N}, \mathrm{w}$ & 75 \\
\hline $\mathrm{AeHi}$ & $10 \mathrm{~N}, \mathrm{c}$ & 83 & $10 \mathrm{~N}, \mathrm{w}$ & 58 \\
\hline $\mathrm{GlTr}$ & $8 \mathrm{~N}, \mathrm{c}$ & 54 & $10 \mathrm{~N}, \mathrm{w}$ & 50 \\
\hline $\mathrm{AiAl}$ & $8 \mathrm{~N}, \mathrm{c}$ & 90 & $9 \mathrm{~N}, \mathrm{w}$ & 73 \\
\hline
\end{tabular}

Table 8 Impact resistance of coated surfaces Tablica 8. Otpornost premazane površine na udarce

\begin{tabular}{|c|c|c|c|c|}
\hline \multirow{2}{*}{$\begin{array}{c}\text { Substrate } \\
\text { Podloga }\end{array}$} & \multicolumn{2}{|c|}{ WPU } & \multicolumn{2}{|c|}{ SPU } \\
\hline & $\begin{array}{c}\text { Dropping } \\
\text { height } \\
\text { Visina udara }\end{array}$ & $\begin{array}{c}\text { Grade* } \\
\text { Ocjena }\end{array}$ & $\begin{array}{c}\text { Dropping } \\
\text { height } \\
\text { Visina udara }\end{array}$ & $\begin{array}{l}\text { Grade** } \\
\text { Ocjena }\end{array}$ \\
\hline FaSy & $10 \mathrm{~mm}$ & 2 & $100 \mathrm{~mm}$ & 3 \\
\hline $\mathrm{AcNe}$ & $10 \mathrm{~mm}$ & 2 & $100 \mathrm{~mm}$ & 1 \\
\hline RoPs & $10 \mathrm{~mm}$ & 3 & $100 \mathrm{~mm}$ & 3 \\
\hline $\mathrm{AeHi}$ & $10 \mathrm{~mm}$ & 2 & $100 \mathrm{~mm}$ & 1 \\
\hline GlTr & $10 \mathrm{~mm}$ & 3 & $200 \mathrm{~mm}$ & 3 \\
\hline $\mathrm{AiAl}$ & $10 \mathrm{~mm}$ & 3 & $200 \mathrm{~mm}$ & 1 \\
\hline
\end{tabular}

*5 - no visible changes (no damage) / nema vidljivih promjena (nema oštećenja)

4 - no cracks in the surface but the impact mark is visible when light from the source is reflected from the surface at or very near the test point / nema pukotina na površini, ali je pri reflektiranju svjetlosti s površine vidljivo mjesto udara

3 - slight cracking at the surface, usually one or two circular cracks within the impact mark / vide se male pukotine na površini, obično jedna ili dvije kružne unutar mjesta udara

2 - moderate to heavy cracking limited to the impact mark / umjereno do intenzivno pucanje ograničeno na mjesto udara

1 - cracks that extend outside the impact mark and/or flaking of the surface finish / pukotine koje se protežu izvan mjesta udara i/ili se ljušti premaz

It is interesting that there were such big differences between surfaces coated with WPU and SPU. With WPU coated surfaces, the film cracked at much lower dropping height $(10 \mathrm{~mm})$ than it was the case with SPU, where the first cracks appeared not before the dropping height of $100 \mathrm{~mm}$. This result is directly connected with the established higher hardness of WPU film and with higher WPU coated surface hardness.

From the results, we can also see the influence of the substrate. In the case of finishing with WPU, we can see that all these substrates cracked at a dropping height of $10 \mathrm{~mm}$, but the amount of cracks was different (grade 3 and 2). Even much higher differences occurred in the case of SPU coated surfaces. There, we had a different minimum dropping height at which the coating cracked and also the grades were different. It is interesting that, in the case of this property this time RoPs systems (WPU and SPU) proved to be the most resistant to impact. This result could be connected to the highest density of RoPa wood (Merela et al., 2019).

\subsection{Finished surface resistance to cold liquids}

3.7. Otpornost površine na hladne tekućine

Assessment of finished wood surface resistance to cold liquids was performed by selection of the most common liquids and test periods that are usually used in the laboratories for such quick evaluation. In the case of 1-h exposure to water, coffee and alcohol (48\% ethanol), all surfaces proved to be totally resistant to these liquids (grade 5). However, in the case of 1-h exposure to red wine, only surfaces finished with SPU and TO had no problems (grade 5), since the surfaces finished with WPU were drastically coloured (grade 1). This proves that, in our case, the resistance to selected liquids was only dependent on the type of finish used.

\subsection{ATR FT-IR spectra}

\subsection{ATR FT-IR spektri}

Infrared spectroscopy is a sensitive and reliable technique that permits to detect the chemical changes of the chemical structure of polymer materials. Figure 4 shows the infrared spectra of WPU, applied on glass, GlTr and RoPs.

The marked bands are discriminative in showing the difference between WPU on glass and WPU on GlTR and RoPs. This proves that the chemical structure of the last two coating films is different. This different chemical structure, which resulted in the yellowish coating film on GlTr and RoPs, can be connected with the extractives from the wood substrates. It is known that wood extractives can migrate into the coating and cause undesired changes in the dry coating film colour (Kúdela and Liptáková, 2006). Among the investigated IAS, the RoPs has the highest value of total content of extractives, determined by speed extraction $(9.26 \% w / w)$, followed by $\operatorname{GlTr}(6.35 \% w / w)$, while the value of other wood species is significantly much lower (Merela et al., 2019). However, to undoubtedly confirm the presence of extractives in the dry coating film, a more detailed analysis of the discriminative peaks should be made.

\section{CONCLUSION \\ 4. ZAKLJUČAK}

The woods of selected invasive alien tree species (IAS) were successfully finished with one-component waterborne finish on acrylate-polyurethane basis 


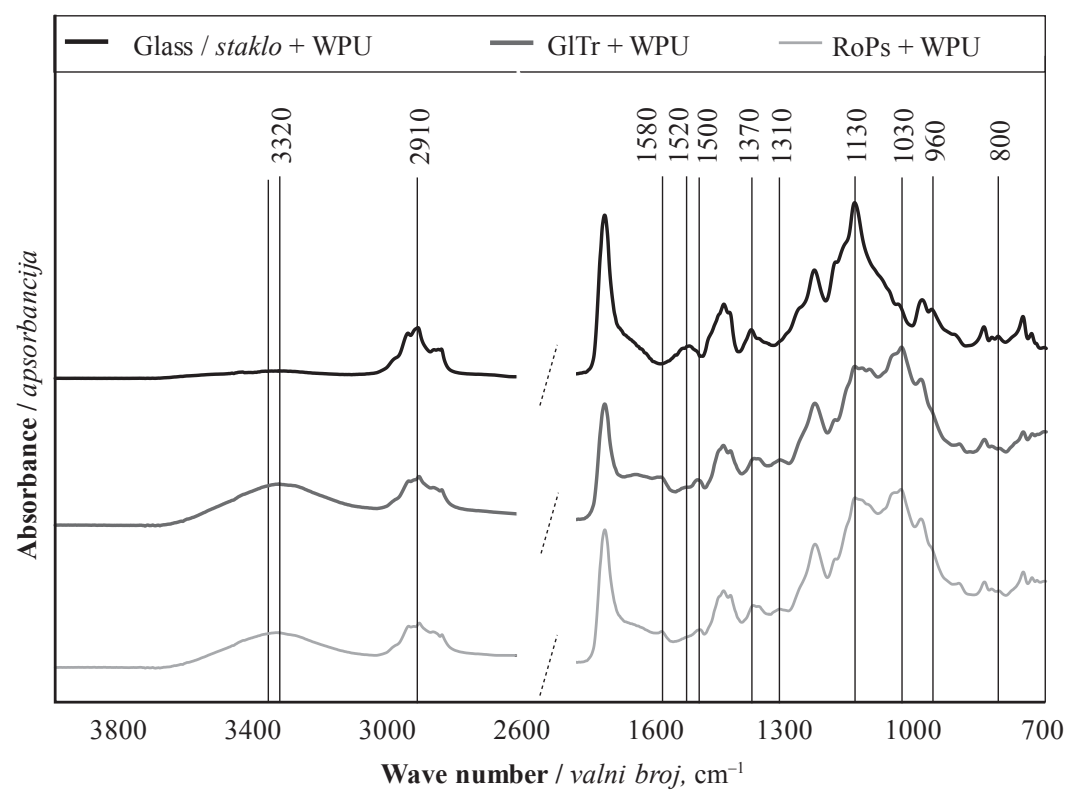

Figure 4 ATR-FTIR spectra of WPU on glass, GlTr and RoPs

Slika 4. ATR-FTIR spektri WPU premaza na staklu, GITr and RoPs

(WPU), one-component solventborne finish on polyurethane basis (SPU) and tung oil (TO). The quality of the surface finishing was evaluated by investigation of various important properties and compared with finishing of most commonly used beech wood.

Interactions between the substrate and finish did have an effect on the drying speed of TO and dry coating film thickness (WPU and SPU). Wood species with higher density had lower oil uptake and consequently oil on those surfaces had longer drying time. Wood species with higher density also had lower uptake of used coatings, which contributed to a higher thickness of the coating films.

The final appearance evaluated by colour and gloss measurements very much depended on the type of the substrate and finish being used. On the black locust (RoPs) and honey locust wood (GlTr), the yellowing of the coating film due to most possible migration of wood extractives was noticed.

Lower coating hardness of SPU compared to WPU resulted in a higher flexibility and higher resistance to impact of SPU systems. It was also shown that surface hardness (determined by scratch test), resistance to impact and coating adhesion are very much related to interactions between the coating and the substrate, while resistance to cold liquids was only dependant on the type of the finish.

In general, woods of the selected IAS are not problematic for finishing. However, it is reasonable to take into account the findings of our study, which also showed that TO cured very slowly on RoPs wood and that the coating film may turn yellow on RoPs and GlTr wood.

\section{Acknowledgements - Zahvala}

This research was done within the project APPLAUSE (UIA02-228) co-financed by the European Regional Development Fund through the Urban Inno- vative Actions Initiative (https://www.ljubljana.si/en/ applause). The authors also acknowledge the financial support from the Slovenian Research Agency (research program funding No. P4-0015, "Wood and lignocellulose composites").

\section{REFERENCES}

\section{LITERATURA}

1. Bačič, T.; Strgulc Krajšek, S., 2013: Invazivne tujerodne rastline pri pouku naravoslovja in biologije. Nova vas in Ljubljana, Zavod Symbiosis in Botanično društvo Slovenije, pp. 5-6.

2. Brischke, C.; Ziegeler, N.; Bollmus, S., 2019: Abrasion resistance of thermally and chemically modified timber. Drvna industrija, 70 (1): 71-76. https://doi.org/10.5552/drvind.2019.1813.

3. Gurleyen, L.; Ayata, U.; Esteves, B.; Cakicier, N., 2017: Effects of heat treatment on the adhesion strength, pendulum hardness, surface roughness, color and glossiness of scots pine laminated parquet with two different types of UV varnish application. Maderas. Ciencia y tecnología, 19 (2): 213-224.

https://doi.org/10.4067/s0718-221x2017005000019.

4. Keskin, H.; Tekin, A., 2011: Abrasion resistances of cellulosic, synthetic, polyurethane, waterborne and acid hardening varnishes used woods. Construction and Building Materials, 25: 638-643. https://doi.org/10.1016/j.conbuildmat.2010.07.028.

5. Kúdela, J.; Liptáková, E., 2006: Adhesion of coating materials to wood. Journal of Adhesion Science and Technology, 20 (8): 875-895.

https://doi.org/10.1163/156856106777638725.

6. Kúdela, J.; Štrbová, M.; Jaš, F., 2016: Influence of accelerated ageing on colour and gloss changes in tree of heaven surface treated with an iruxil coating system. Acta facultatis xylologiae Zvolen, 58 (1): 25-34.

7. Kúdela, J.; Štrbová, M.; Jaš, F., 2017: Influence of accelerated ageing on morphology and wetting of wood surface treated with a modified water-based coating system. Acta facultatis xylologiae Zvolen, 59 (1): 27-39. 
8. Ma, X.; Qiao, Z.; Huang, Z.; Jing, X., 2013: The dependence of pendulum hardness on the thickness of acrylic coating. Journal of Coatings Technology and Research, 10 (3) 433-439.

https://doi.org/10.1007/s11998-013-9477-3.

9. Merela, M.; Humar, M.; Kariž, M.; Šega, B.; Žigon, J.; Fajdiga, G.; Merhar, M.; Vek, V.; Poljanšek, I.; Oven, P.; Krapež, D.; Vivod, B.; Straže, A.; Gorišek, Ž.; Čufar, K.; Krže, L.; Petrič, M.; Pavlič, M., Gornik Bučar, D.; Šernek, M.; Balzano, A.; Vidic, D.; Planinšič, J.; Rajh, D., 2019: WP4 Identification, collection and processing of IAPS: A.4.1 - Analysis of structure and relevant properties of selected IAPS: D 4.1.2 - Laboratory analysis of suitability for processing into wood product for 17 woody IAPS. Ljubljana, Biotehniška fakulteta, Oddelek za lesarstvo, $186 \mathrm{p}$.

10. Németh, R.; Molnárné Posch, P.; Molnár, S.; Bak, M., 2014: Performance evaluation of strip parquet flooring panels after long-term, in-service exposure. Drewno, 57 (193): 119-134.

11. Pánek, M.; Reinprecht, L., 2014: Colour stability and surface defects of naturally aged wood treated with transparent paints for exterior constructions. Wood Research, 59 (3): 421-430.

12. Pánek, M.; Reinprecht, L., 2016: Effect of the number of UV-protective coats on the color stability and surface defects of painted black locust and norway spruce woods subjected to natural weathering. BioResources, 11 (2): 46634676. https://doi.org/10.15376/biores.11.2.4663-4676.

13. Pánek, M.; Reinprecht, L., 2019: Critical view on the possibility of color changes prediction in the surfaces of painted wood exposed outdoors using accelerated weathering in Xenotest. Journal of Coatings Technology and Research, 16 (2): 339-352. https://doi.org/10.1007/s11998-018-0125-9.

14. Pavlič, M.; Kričej, B.; Tomažič, M.; Petrič, M., 2003: Kakovost površinskih sistemov pohištva slovenskih proizvajalcev / Quality of surface furniture systems of Slovenian producers. Les/Wood, 55 (10): 322-327.

15. Robinson, S. C.; Tudor, D.; Mansourian, Y.; Cooper, P. A., 2013: The effects of several commercial wood coatings on the deterioration of biological pigments in wood exposed to UV light. Wood Science and Technology, 47: 457-466. https://doi.org/10.1007/s00226-012-0502-y.

16. Sönmez, A.; Budakçı, M.; Pelit, H., 2011: The effect of the moisture content of wood on the layer performance of water-borne varnishes. BioResources, 6 (3), 3166-3178.
17. Veigel, S.; Grüll, G.; Pinkl, S.; Obersriebnig, M.; Müller, U.; Gindl-Altmutter, W., 2014: Improving the mechanical resistance of waterborne wood coatings by adding cellulose nanofibers. Reactive and Functional Polymers. 85: 214-220. https://doi.org/10.1016/j.reactfunctpolym.2014.07.020.

18. Wang, X.; Wang, F.; Yu, Z.; Zhang, Y.; Qi, C.; Du, L., 2017: Surface free energy and dynamic wettability of wood simultaneously treated with acidic dye and flame retardant. Journal of Wood Science, 63 (3): 271-280. https://doi.org/10.1007/s10086-017-1621-8.

19. Yang, X.; Zhang, S.; Li, W., 2015: The performance of biodegradable tung oil coatings. Progress in Organic Coatings 85: 216-220. https://doi.org/10.1016/j.porgcoat.2015.04.015.

20. ***DIN 53 150, 2002: Paints and varnishes - Determination of the drying stage of coatings (modified BandowWolff method).

21. ***SIST EN 12720, 2009: Furniture - Assessment of surface resistance to cold liquids.

22. ***SIST EN ISO 11664-4, 2011: Colorimetry. Part 4: CIE 1976 L*a*b* Color space (ISO 11664-4:2008).

23. ***SIST EN ISO 1518, 2001: Paints and varnishes Scratch test (ISO 1518:1992).

24. ***SIST EN ISO 1522, 2007: Paints and varnishes Pendulum damping test (ISO 1522:2006).

25 . ***SIST EN ISO 2808, 2007: Paints and varnishes - Determination of film thickness (ISO 2808:2007).

26. ***SIST EN ISO 2813, (2015): Paints and varnishes Determination of gloss value at 20 degrees, 60 degrees and 85 degrees (ISO 2813:2014).

27. ***SIST EN ISO 4624, 2016: Paints and varnishes Pull-off test for adhesion (ISO 4624:2016).

28. ***SIST ISO 4211-4, 1995: Furniture - Test for surfaces. Part 4: Assessment of resistance to impact.

\section{Corresponding address:}

\section{MATJAŽ PAVLIČ, PhD}

University of Ljubljana

Biotechnical Faculty

Department of Wood Science and Technology

Jamnikarjeva 101, 1000 Ljubljana, SLOVENIA

e-mail: matjaz.pavlic@bf.uni-lj.si 